\title{
Pengaruh Efektivitas Sistem Informasi Akuntansi Terhadap Kinerja Individual dengan Insentif Sebagai Variabel Pemoderasi Pada LPD
}

\author{
I Kadek Indra Suryawan ${ }^{1}$ \\ I Gusti Ngurah Agung Suaryana ${ }^{2}$ \\ ${ }^{1}$ Fakultas Ekonomi dan Bisnis Universitas Udayana (Unud), Bali, Indonesia \\ email: indrasuryawan420@gmail.com/ Tlp: +6283192734889 \\ ${ }^{2}$ Fakultas Ekonomi dan Bisnis Universitas Udayana (Unud), Bali, Indonesia
}

\begin{abstract}
ABSTRAK
Teknologi informasi saat ini bukan menjadi tuntutan lagi bagi perusahaan atau organisasi, melainkan sudah menjadi kebutuhan untuk menunjukkan kerja entitas perusahaan atau organisasi tersebut. Peranan insentif diharapkan dapat merangsang disiplin kerja karyawan, agar dapat meningkatkan produktivitas dan prestasi kerja karyawan sehingga tujuan suatu perusahaan dapat diwujudkan. Penelitian ini dilakukan di Lembaga Perkreditan Desa di Kecamatan Sukawati. Tujuan penelitian adalah untuk mengetahui pengaruh efektivitas sistem informasi akuntansi pada kinerja individual dengan insentif sebagai pemoderasi pada Lembaga Perkreditan Desa di Kecamatan Sukawati. 99 sampel terpilih dengan teknik sampling jenuh. Hipotesis di uji dengan menggunakan analisis regresi moderasi. Hasil analisis adalah tingkat efektivitas sistem informasi akuntansi berpengaruh positif terhadap kinerja individual. Insentif dapat memperkuat pengaruh efektivitas sistem informasi terhadap kinerja individual.
\end{abstract}

Kata kunci: Efektivitas sistem informasi akuntansi, insentif, kinerja individual

\begin{abstract}
Information technology today is no longer a demand for companies or organizations, but has become a necessity to demonstrate the work of corporate entities or organizations. The role of incentives is expected to stimulate employee work discipline, in order to improve productivity and employee performance so that the goals of a company can be realized. This research was conducted at Lembaga Perkreditan Desa in Sukawati Subdistrict. The purpose of this study was to determine the effect of effectiveness of accounting information system on individual performance with incentives as moderator at Lembaga Perkreditan Desa in Sukawati Subdistrict. 99 samples were selected with saturated sampling technique. The hypothesis was tested using moderation regression analysis. The results of the analysis is the effectiveness of accounting information system has a positive effect on individual performance. Incentives can strengthen the effect of information system effectiveness on individual performance.

Keywords: Effectiveness of accounting information system, incentive, individual performance
\end{abstract}

\section{PENDAHULUAN}

Pesatnya perkembangan teknologi menyebabkan informasi dengan mudah sampai

kepada masyarakat sehingga menjadikan sebagian besar masyarakat semakin merasakan informasi sebagai salah satu kebutuhan penting disamping kebutuhan 
I Kadek Indra Suryawan dan I Gusti Ngurah Agung Suaryana. Pengaruh...

lainnya. Teknologi informasi dengan komputer sebagai motor penggeraknya telah mempermudah segalanya. Kelton et al (2010) menyatakan bahwa teknologi informasi berkembang dengan pesat, sehingga mempunyai dampak yang positif dan signifikan bagi perusahaan. Kelangsungan hidup perusahaan sangat ditentukan oleh kemampuannya bersaing. Kemampuan bersaing memerlukan strategi yang dapat memanfaatkan semua kekuatan dan peluang yang ada, serta menutup kelemahan dan menetralisasi hambatan strategis yang dihadapi dalam bisnis. Teknologi informasi dapat didefinisikan sebagai perpaduan antara beberapa teknologi berbasis komputer dan telekomunikasi, seperti perangkat keras, perangkat lunak, teknologi jaringan, database, dan peralatan telekomunikasi lainnya.

Sistem Informasi (SI) memiliki peran yang sangat penting di dalam bidang akuntansi, karena pada dasarnya tujuan utama akuntansi adalah menyediakan informasi untuk para pengambil keputusan. Secara umum semua perusahaan atau organisasi akan selalu membutuhkan informasi untuk mengambil sebuah keputusan. Informasi yang dibutuhkan haruslah informasi yang akurat, yang tersedia tepat waktu kapanpun dibutuhkan, dan memiliki nilai yang tepat dan relevan (Deny,2014).

Informasi diharapkan mampu meningkatkan efektivitas sistem yang digunakan dalam perusahaan. Efektivitas adalah suatu ukuran yang memberikan gambaran seberapa jauh target dapat dicapai, baik secara kualitas maupun waktu, orientasinya adalah pada keluaran (output) yang dihasilkan (Yamit, 2003:14). Suatu sistem dapat dikatakan efektif apabila mampu menghasilkan informasi yang 
berkualitas dan mampu membantu kinerja penggunanya. Informasi Akuntansi yang berkualitas berperan penting untuk peningkatan efektivitas dan pengelolaan setiap organisasi karena data dan informasi menjadi dasar atas kegiatan usaha individu (Nwokeji, 2012).

Teori tentang penggunaan teknologi sistem informasi dikenal dengan nama Technology Acceptance Model (TAM) yang mengasumsikan bahwa penggunaan sistem pada kenyataannya ditentukan oleh niat perilaku pengguna yang didasarkan pada persepi kebermanfaatan (Perceived Usefulness) dan kemudahan penggunaan (Perceived Ease of Use). TAM menyatakan bahwa secara keseluruhan prilaku manusia dapat dijelaskan dengan mempertimbangkan kepercayaannya. Dapat dikatakan bahwa seorang individu akan menggunakan teknologi sistem informasi dengan baik apabila sistem tersebut mudah digunakan serta menghasilkan manfaat dan menguntungkan dalam peningkatan kinerjanya (Davis et al. (1989).

Sistem Informasi Akuntansi di definisikan sebagai sistem alat yang dimasukkan ke dalam bidang teknologi informasi, yang dirancang untuk membantu pengelolaan dan pengendalian topik yang terkait dengan bidang ekonomi dan keuangan perusahaan (Urquia et al, 2011). SIA adalah komponenkomponen yang saling berhubungan yang terintegrasi untuk mengumpulkan, menyimpan, dan menyebarkan data untuk tujuan perencanaan, pengendalian, koordinasi, analisis, dan pengambilan keputusan (Soudani, 2012). Penggunaan SIA tentunya harus diimbangi dengan kemampuan teknik atau sumber daya manusia dari penggunannya karena keberhasilan SIA sangat ditentukan oleh 
I Kadek Indra Suryawan dan I Gusti Ngurah Agung Suaryana. Pengaruh...

kemampuan teknik penggunanya agar sistem berjalan sesuai fungsinya. Sehingga dampak penerapan SIA dilihat dari sisi positif dapat mempermudah hubungan yang terintegrasi untuk mengumpulkan, menyimpan dan meyebarkan data dengan tujuan perencanaan pengendalian untuk mengambil keputusan dan dari sisi negatif penerapan SIA tergolong membutuhkan biaya yang cukup besar, terkait pendidikan dan pelatihan dalam penerapan SIA.

Efektivitas teknologi sistem informasi akuntansi merupakan suatu ukuran yang memberikan gambaran sejauh mana target dapat dicapai dari suatu kumpulan sumber daya yang diatur untuk mengumpulkan, memproses, dan menyimpan data elektronik, kemudian mengubahnya menjadi sebuah informasi yang berguna serta menyediakan laporan formal yang dibutuhkan dengan baik secara kualitas maupun waktu (Damayanthi, 2012). Sistem informasi akuntansi dikatakan efektif bila informasi yang diberikan oleh sistem tersebut dapat melayani kebutuhan pengguna sistem. Semakin efektif sistem informasi akuntansi akan membuat kinerja semakin tinggi.

Insentif adalah suatu penghargaan dalam bentuk material atau non material yang diberikan oleh pihak pimpinan organisasi perusahaan kepada karyawannya dengan tujuan agar mereka bekerja dengan motivasi yang tinggi dan berprestasi dalam mencapai tujuan-tujuan perusahaan, dengan kata lain pemberian insentif adalah pemberian uang diluar gaji sebagai pengakuan perusahaan terhadap prestasi kerja dan kontribusi karyawannya (Verbeeten, 2008). Menurut Handoko (2002: 176) insentif adalah perangasang yang ditawarkan kepada para karyawan untuk melaksanakan kinerja sesuai atau lebih tinggi dari standar-standar yang 
telah ditetapkan. Pemberian insektif kepada karyawan merupakan upaya untuk memelihara karyawan agar bisa bekerja lebih baik dan maksimal. Insentif dikatakan sebagai imbalan atas atas prestasi, semakin tinggi prestasi karyawan maka seharusnya perusahaan juga memberikan imbalan lebih kepada karyawannya. Menurut Dwijayanti (2014) insentif berpengaruh positif dan signifikan terhadap kinerja individu pengguna sistem informasi akuntansi pada SKPD Dispenda Pemerintah Kota Denpasar.

Kinerja individu adalah kemampuan individu untuk menyelesaikan suatu pekerjaan dengan berhasil dan efisien pada suatu perusahaan. Kinerja individual adalah suatu kondisi yang harus diketahui dan dikonfirmasikan kepada pihak yang berkepentingan untuk mengetahui tingkat pencapaian tujuan suatu organisasi (George et al., 2012). Keberhasilan sistem informasi suatu perusahaan bergantung kepada bagaimana sistem itu dijalankan, kemudahan sistem itu bagi para pemakainya, dan pemanfaatan teknologi yang digunakan. Sistem informasi akuntansi yang digunakan dapat memonitoring dan membantu proses kinerja sehingga dapat meningkatkan kualitas pelayanan pada lembaga tersebut (Damayanti, 2012). Kinerja organisasi secara keseluruhan dapat ditingkatkan melalui kinerja individual yang tinggi (Lindawati,2012).

Keberhasilan perusahaan dalam mencapai sebuah tujuan dan memenuhi kebutuhan masyarakat sangat bergantung pada kinerja karyawan. Menyediakan laporan keuangan yang relevan dan reliabel yang dapat digunakan sebagai informasi dan dasar untuk pengambilan keputusan adalah upaya peningkatan kinerja individual dalam sudut pandang akuntansi. Kinerja yang baik dapat terlihat 
I Kadek Indra Suryawan dan I Gusti Ngurah Agung Suaryana. Pengaruh...

apabila individu dapat menyelesaikan dan melaksanakan tugasnya dengan baik. Individu diharapkan dapat menyelesaikan pekerjaannya dengan bantuan teknologi dan dengan pemberian insektif kepada karyawan merupakan upaya untuk memelihara karyawan agar bisa bekerja lebih baik dan maksimal. Sehingga insentif akan dapat meningkatkan kinerja individual dalam mengoprasikan sistem informasi akuntansi dalam LPD.

Sistem informasi akuntansi memiliki peranan yang sangat potensial dalam pengembangan dan penyediaan informasi sebagai pengendalian manajemen dan membantu dalam pengambilan sebuah keputusan. Lembaga keuangan mulai memanfaatkan Sistem Informasi Akuntansi berbasis komputer, salah satunya adalah Lembaga Perkreditan Desa. Lembaga Perkreditan Desa (LPD) merupakan badan usaha keuangan milik desa pekraman dimana lembaga ini melakukan kegiatan operasionalnya di lingkungan desa untuk melayani masyarakat desa setempat. LPD bertujuan untuk mendorong pembangunan ekonomi pada masyarakat desa melalui pemberian kredit maupun simpanan dalam bentuk tabungan. Lapangan usaha Lembaga Perkreditan Desa mencakup menerima atau menghimpun dana dari krama desa dalam bentuk tabungan dan deposito, memberikan pinjaman hanya kepada krama desa adat, dan menerima pinjaman dari lembaga-lembaga keuangan maksimum sebesar 100\% dari jumlah modal, termasuk cadangan dan laba ditahan kecuali batasan lain dalam jumlah pinjaman atau dukungan dan bantuan dana.

Peningkatan kinerja individual pengurus LPD sangat dibutuhkan untuk perkembangan LPD sehingga dapat bersaing dengan lembaga keuangan lainnya. 
Pemilihan pengurus LPD diputuskan berdasarkan paruman di desa pakraman LPD tersebut. Paruman adalah Pertemuan yang dilakukan oleh krama adat untuk membahas masalah tertentu yang keputusannya diambil berdasarkan musyawarah mufakat bersama. Jadi, pemilihan pengurus LPD tersebut tidak berdasarkan latar belakang pendidikan namun lebih mengutamakan kejujuran. Cara pemilihan karyawan inilah yang membuat LPD menjadi unik karena memiliki perbedaan dari lembaga keuangan yang lainnya.

Penelitian ini ingin menguji kembali pengaruh variabel efektivitas SIA pada variabel kinerja individual. Penelitian mengenai pengaruh efektivitas SIA terhadap kinerja individual telah dilakukan pada penelitian sebelumnya tetapi terjadi ketidakkonsistenan hasil penelitian mengenai hubungan tersebut. Hasil penelitan seperti pada penelitian Puja dan Suardikha (2013), Marlinawati dan Suaryana (2013), Puji dan Dharmadiaksa (2014), serta Mercika dan Jati (2015) menunjukan hasil bahwa efektivitas sistem informasi akuntansi berpengaruh positif dan signifikan terhadap kinerja individu dan karyawan. Namun sebaliknya disisi lain juga terdapat penelitian yang menunjukan bahwa pemakaian sistem informasi akuntansi tidak dapat meningkatkan profitabilitas, kinerja individu, dan efisiensi operasi seperti pada penelitian (Urqia et al., 2010), (kouser et al., 2011) dan (kharuddin et al., 2010). Soudani (2012) juga menemukan hasil penelitian yang menunjukan hasil yang tidak mendukung adanya hubungan yang positif antara sistem informasi akuntansi terhadap kinerja. Berdasarkan hal tersebut, perlu dilakukan penelitian mengenai pengaruh efektivitas sistem informasi akuntansi 
I Kadek Indra Suryawan dan I Gusti Ngurah Agung Suaryana. Pengaruh...

pada kinerja individual dengan insentif sebagai variabel moderasi di Lembaga Perkreditan Desa di kecamatan Sukawati.

Efektivitas sistem informasi akuntansi yaitu gambaran sejauh mana target dicapai dari suatu kumpulan sumber daya yang diatur untuk mengumpulkan, memproses, dan menyimpan data elektronik, kemudian mengubahnya menjadi informasi yang berguna serta menyediakan laporan formal yang dibutuhkan dengan baik secara kualitas maupun waktu (Damayanthi, 2012). TAM meyakini bahwa penggunaan sistem informasi akan meningkatkan kinerja individu atau organisasi (Gupta et al, 2007). Penelitian yang dilakukan oleh Sugiartini (2016) yang mengatakan bahwa efektivitas sistem informasi akuntansi berpengaruh positif terhadap kinerja individual.

Novita (2011) menyebutkan bahwa semakin efektif sistem informasi akuntansi akan membuat kinerja semakin tinggi. Senada dengan hal tersebut, Salehi, dkk. (2010) yang mengatakan beberapa organisasi bisnis mendapatkan keunggulan kompetitif dengan melengkapi sistem informasinya, dengan demikian kinerja individual karyawan juga akan semakin efektif. Penelitian dengan hasil serupa juga dilakukan oleh Suryandari (2011) yang menyebutkan bahwa semakin efektif sistem informasi akuntansi akan membuat kinerja semakin tinggi. Suratini (2015) menyatakan bahwa efektivitas sistem informasi akuntansi berpengaruh positif dan signifikan terhadap kinerja individual. Berdasarkan uraian di atas, maka rumusan hipotesis yang digunakan adalah :

$\mathrm{H}_{1}$ : Efektivitas sistem informasi akuntansi berpengaruh positif pada kinerja individual. 
Pemakai sistem informasi akuntansi berperan penting dalam kemajuan suatu perusahaan. Pemakai sistem informasi akuntansi dapat mendorong kinerja sistem informasi menjadi lebih baik. Kinerja sistem informasi berjalan dengan baik apabila para pemakai dapat memahami, menggunakan, dan mengaplikasikan sebuah teknologi menjadi sebuah informasi yang berguna untuk pengambilan keputusan sehingga tujuan perusahaan dapat terpenuhi dan kinerja individual dapat dinilai baik.

Insentif sebagai sarana motifasi yang mendorong para pegawai untuk bekerja dengan kemampuan yang optimal, yang dimaksudkan sebagai pendapatan ektra di luar gaji atau upah yang telah ditentukan. Pemberian insentif dimaksudkan agar dapat memenuhi kebutuhan para pegawai dan keluarga meraka. Iatilah sistem insentif pada umumnya digunakan untuk menggambarkan rencanarencana pembayaran kualitas yang tercapai oleh seseorang karyawan dalam melaksanakan tugasnya sesuai dengan tanggung jawab yang diberikan kepadanya.

Menurut Dwijayanthi (2013) insentif secara parsial berpengaruh signifikan terhadap kinerja individual pengguna sisitem informasi akuntansi pada SKPD Dispenda kota denpasar. Novita (2011) menyebutkan bahwa semakin efektif sistem informasi akuntansi akan membuat kinerja semakin tinggi. Jadi dengan adanya insentif sebagai motivasi yang mendorong kinerja karyawan menjadi lebih baik lagi, diharapkan dapat meningkatakan pengaruh efektivitas sistem informasi terhadap kinerja individual. Didukung pula dengan pernyataan dari Casio (1995:377) yang menyebutkan insentif adalah variabel penghargaan yang diberikan kepada individu dalam suatu kelompok, yang diketahui berdasarkan 
I Kadek Indra Suryawan dan I Gusti Ngurah Agung Suaryana. Pengaruh...

perbedaan dalam mencapai hasil kerja. Menurut Utari Sinta (2014) pengaruh insentif terhadap kinerja individual pada LPD di kota denpasar berpengaruh positif dan signifikan. Berdasarkan uraian di atas, maka rumusan hipotesis yang digunakan adalah :

$\mathrm{H}_{2}$ : Insentif memperkuat pengaruh efektivitas sistem informasi akuntansi pada kinerja individual.

\section{METODE PENELITIAN}

Pendekatan yang digunakan dalam penelitian ini adalah pendekatan kuantitatif yang berbentuk asosiatif. Penelitian kuantitatif merupakan penelitian yang lebih menekankan pengujian teori melalui pengukuran variabel penelitian dengan angka serta data analisis menggunakan prosedur statistik (Indriantoro dan Supomo, 2013:12). Penelitian asosiatif adalah dugaan tentang adanya hubungan antar variabel dalam populasi yang akan diuji melalui hubungan antar variabel dalam sampel yang diambil dari populasi tersebut (Sugiyono, 2013:224). Pada penelitian ini variabel yang diuji yaitu pengaruh efektivitas sistem informasi akuntansi terhadap kinerja individual yang dimoderasi oleh insentif. Berikut merupakan gambar desain dari penelitian ini.

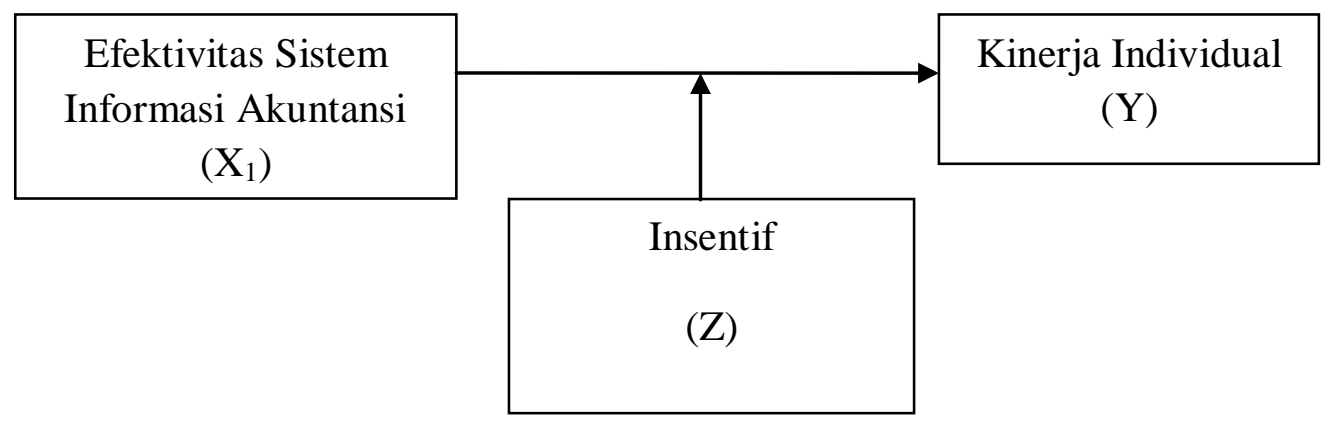

Gambar 1. Desain Penelitian 
Lokasi dalam penelitian ini dilakukan pada Lembaga Perkreditan Desa (LPD) di kecamatan sukawati. Perkembangan lembaga keuangan yang pesat memicu persaingan ketat antara LPD dengan lembaga keuangan lainnya, untuk itu diperlukan sistem informasi akuntansi untuk meningkatkan kinerja LPD sehingga dapat bersaing dengan lembaga keuangan lainnya.

Variabel terikat dalam penelitian ini adalah kinerja individual, yang diukur dengan menggunakan lima indikator yaitu kuantitas kerja (quantity), kualitas kerja (quality), ketepatan waktu (timeliness), pengawasan supervisor (need for supervisor) dan pengaruh rekan kerja (interpersonal impact). Variabel bebas dalam penelitian ini adalah efektivitas sistem informasi akuntansi, yang diukur menggunakan enam indikator yaitu kualitas sistem (system quality), kualitas informasi (information quality), kualitas layanan (service quality), pengguna informasi (information use), kepuasan pengguna (user satisfaction), dan manfaat penggunaan (net benefit). Variabel pemoderasi dalam penelitian ini adalah insentif yang diukur enam indicator yaitu Penghargaan atas prestasi yang dicapai, Insentif yang diberikan berupa dana pensiun, pemberhentian atau pensiun, Insentif berupa uang tunai atau sertifikat, Insentif yang diterima sudah memenuhi kebutuhan karyawan, Insentif yang diberikan sesuai dengan badan kerja, Insentif yang diterima dapat memicu kinerja.

Pengukuran masing-masing variabel efektivitas sistem informasi akuntansi, kinerja individual dan insentif dilakukan dengan menggunakan kuisioner skala likert dengan skala yang digunakan yaitu skala 4 poin, di mana poin 1 adalah Sangat Tidak Setuju (STS), poin 2 adalah Tidak Setuju (TS), poin 3 
I Kadek Indra Suryawan dan I Gusti Ngurah Agung Suaryana. Pengaruh...

adalah Setuju (S), dan poin 4 adalah Sangat Setuju (SS). Alasan menggunakan modifikasi skala likert dengan rentang 1 sampai 4 dalam penelitian ini adalah untuk menghindari adanya tendensi efek kencenderungan responden memilih jawaban ditengah atau jawaban ragu-ragu yang dapat mempengaruhi keandalan data yang dihasilkan (Efferin, dkk, 2008: 109). Dengan menggunakan skala Likert 1-4 maka responden diharapkan untuk secara tegas menyampaikan pendapatnya, apakah setuju atau tidak setuju atas suatu pernyataan atau pertanyaan dalam kuesioner.

Jenis data yang digunakan dalam penelitian ini adalah data kuantitatif yang berupa hasil kuesioner Lembaga Perkreditan Desa, dan jumlah karyawan Lembaga Perkreditan Desa di Kecamatan Sukawati dan data kualitatif yang berupa daftar nama Lembaga Perkreditan Desa di Kecamatan Sukawati. Sedangkan, sumber data yang digunakan dalam penelitian ini adalah data primer yang berupa jawaban responden terhadap pernyataan kuesioner dan data sekunder yang berupa daftar nama Lembaga Perkreditan Desa di Kecamatan Sukawati.

Populasi dalam penelitian ini adalah seluruh karyawan pada Lembaga Perkreditan Desa di Kecamatan Sukawati yang berjumlah 99 orang, di mana penentuan sampel dilakukan menggunakan metode purposive sampling agar memperoleh sampel yang representatif, sesuai dengan kriteria yang telah ditentukan. Hasil penentuan sampel penelitian ini dapat dilihat pada Tabel 1 sebagai berikut. 
Tabel 1.

Sampel Penelitian

\begin{tabular}{llc}
\hline No & \multicolumn{1}{c}{ Keterangan } & Jumlah \\
\hline 1 & Jumlah LPD di kecamatan sukawati & 33 \\
2 & Jumlah anggota populasi. & 99 \\
\hline \multicolumn{2}{l}{ Jumlah sampel } & 99 \\
\hline
\end{tabular}

Sumber: Data diolah, 2017

Metode pengumpulan data yang digunakan dalam penelitian ini adalah metode wawancara dan kuesioner. Metode wawancara dilakukan dengan mewawancarai pimpinan dan karyawan Lembaga Perkreditan Desa yang terlibat langsung dalam pemanfaatan sistem informasi akuntansi. Sedangkan, metode kuesioner dilakukan dengan menyebarkan secara langsung kepada kepala LPD, bendahara dan tata usaha di Lembaga Perkreditan Desa di Kecamatan Sukawati.

Teknik analisis data yang digunakan dalam penelitian ini adalah Moderate Regression Analysis untuk mengukur interaksi yaitu perkalian dua atau lebih variabel bebas (Liana, 2009). Bentuk persamaan yang digunakan adalah sebagai berikut:

$$
\mathrm{Y}=\alpha+\beta_{1} \mathrm{X}_{1}+\beta_{2} \mathrm{X}_{2}+\beta_{3} \mathrm{X}_{1} \mathrm{X}_{2}+\varepsilon
$$

Keterangan :

$$
\begin{array}{ll}
\mathrm{Y} & =\text { Kinerja individual } \\
\alpha & =\text { Konstanta } \\
\beta_{1}, \beta_{2}, \beta_{3} & =\text { koefisien } \\
\mathrm{X}_{1} & =\text { Efektivitas sistem informasi akuntansi } \\
\mathrm{Z} & =\text { Insentif } \\
\varepsilon & =\text { Eror }
\end{array}
$$

\section{HASIL DAN PEMBAHASAN}

Penelitian ini menggunakan kuesioner sebagai instrumen untuk mengumpulkan data penelitian, berupa pendapat para responden atas serangkaian pernyataan atau 
I Kadek Indra Suryawan dan I Gusti Ngurah Agung Suaryana. Pengaruh...

pertanyaan yang terdapat di dalam kuesioner. Sampel dalam penelitian ini adalah karyawan yang menduduki jabatan dalam Lembaga Perkreditan Desa di Kecamatan Sukawati, yang meliputi kepala LPD, karyawan bagian Bendahara dan Tata usaha. Kuisioner ini disebarkan pada 33 Lembaga Perkreditan Desa di Kecamatan Sukawati yang telah menggunakan Sistem Informasi Akuntansi minimal selama satu tahun. Kurun waktu selama satu tahun digunakan karena Lembaga Perkreditan Desa yang telah menggunakan Sistem Informasi Akuntansi selama satu tahun diasumsikan memiliki karyawan yang lebih berpengalaman dalam mengoperasikan Sistem Informasi Akuntansi dibandingkan karyawan pada Lembaga Perkreditan Desa yang baru menggunakan Sistem Informasi Akuntansi.

Waktu penyeberan kuesioner dimulai pada tanggal 26 september 2017 sampai 26 oktober 2017. Kuesioner yang disebarkan sebanyak 99 kuesioner dengan tingkat pengembalian responden (response rate) sebesar 100 persen dan tingkat pengembalian yang dapat dianalisis (useable response rate) sebesar 100 persen dengan rincian seperti Tabel 2 sebagai berikut.

Tabel 2.

\section{Rincian Pengiriman dan Pengembalian Kuesioner}

\begin{tabular}{lc}
\hline Keterangan & Jumlah \\
\hline Kueisoner yang disebar & 99 \\
Kuesioner yang tidak dikembalikan & 0 \\
Kueisoner yang dikembalikan & 99 \\
Kueisoner yang gugur (tidak lengkap) & 0 \\
Kuesioner yang digunakan & 99 \\
\hline Tingkat pengembalian (responserate) & $100 \%$ \\
Tingkat pengembalian yang digunakan (usable responserate) & $100 \%$ \\
\hline Sumber: Data diolah, 2017 &
\end{tabular}

Tabel 2 menunjukkan bahwa jumlah kuesioner yang terpakai adalah 99 (100\%), artinya seluruh kuesioner yang disebar dapat digunakan. Setiap Lembaga 
Perkreditan Desa di Kecamatan Sukawati mendapatkan kuesioner dimana terdapat 33 LPD di Kecamatan Sukawati.

Karakteristik responden penelitian merupakan profil dari 99 responden yang berpartisipasi dalam pengisian kuesioner penelitian ini. Data penelitian diperoleh dari hasil kuesioner yang telah disebarkan kepada responden penelitian yang berjumlah 99 orang. Karakteristik responden yang diteliti meliputi jenis kelamin dan tingkat pendidikan responden. Ringkasan mengenai karakteristik responden dapat dilihat pada Tabel 3 sebagai berikut.

Tabel 3.

Karakteristik Responden

\begin{tabular}{lcccc}
\hline No & Variabel & Klasifikasi & Jumlah (Orang) & Persentase \\
\hline \multirow{2}{*}{1} & \multirow{2}{*}{ Jenis Kelamin } & Laki-Laki & 37 & $37,4 \%$ \\
& & Perempuan & 62 & $62,6 \%$ \\
\hline \multirow{2}{*}{ Jumlah } & & 99 & $100 \%$ \\
\hline \multirow{2}{*}{2} & \multirow{2}{*}{ Tingkat Pendidikan } & SMA/Sederajat & 48 & $48,5 \%$ \\
& & Diploma & 19 & $19,2 \%$ \\
& S1 & 29 & $29,3 \%$ \\
& S2 & 3 & $3,0 \%$ \\
\hline
\end{tabular}

Sumber: Data diolah, 2017

Berdasarkan data penelitian dapat diketahui karakteristik dari responden yang berpartisipasi dalam penelitian ini. Menurut jenis kelamin dapat diketahui bahwa terdapat 62 responden $(62,6 \%)$ berjenis kelamin perempuan, dan sisanya sebanyak 37 orang responden $(37,4 \%)$ berjenis kelamin laki-laki. Hal ini menunjukkan bahwa karyawan berjenis kelamin perempuan lebih banyak menduduki jabatan pada Lembaga Perkreditan Desa di Kecamatan Sukawati dibandingkan karyawan berjenis kelamin laki-laki. 
I Kadek Indra Suryawan dan I Gusti Ngurah Agung Suaryana. Pengaruh...

Selain itu, menurut tingkat pendidikan terakhir karyawan dapat diketahui bahwa terdapat 48 responden $(48,5 \%)$ memiliki pendidikan terakhir SMA, 29 responden $(29,3 \%)$ memiliki pendidikan terakhir diploma, 19 responden $(19,2 \%)$ memiliki pendidikan terakhir Strata 1 dan 3 responden $(3,0 \%)$ memiliki pendidikan terakhir Strata 2. Hal ini menunjukkan bahwa mayoritas karyawan Lembaga Perkreditan Desa di kota Denpasar memiliki tingkat pendidikan yang masih rendah dibandingkan dengan lembaga-lembaga keuangan lainnya yang mayoritas karyawannya minimal berpendidikan Strata 1. Hal ini dapat berdampak pada kurang profesionalnya karyawan dalam mengelola LPD, terutama dalam konteks ini kurangnya kemampuan karyawan dalam mengoperasikan Sistem Informasi Akuntansi.

Pengujian statistik deskriptif memberikan gambaran umum tentang sampel, seperti nilai tertinggi, nilai terendah, nilai rata-rata dan standar deviasi dari masingmasing variabel dalam penelitian. Hasil analisis statistik deskriptif dapat dilihat pada Tabel 4 sebagai berikut.

Tabel 4.

Hasil Statistik Deskriptif

\begin{tabular}{lccccc}
\hline & N & Minimum & Maximum & Mean & Std. Deviation \\
\hline Efektivitas Sistem & 99 & 8 & 32 & 25.82 & 7.186 \\
Informasi Akuntansi & 99 & 6 & 24 & 19.21 & 5.657 \\
Insentif & 99 & 10 & 24 & 20.39 & 4.733 \\
Kinerja Individual & & & &
\end{tabular}

Sumber: Data diolah, 2017

Berdasarkan Tabel 4 dapat diketahui bahwa variabel efektivitas sistem informasi akuntansi $\left(\mathrm{X}_{1}\right)$ mempunyai nilai minimum sebesar 8 , nilai maksimum 
sebesar 32, dan nilai rata-rata sebesar 25,82. Hal ini berarti bahwa berdasarkan hasil statistik deskriptif efektivitas sistem informasi akuntansi Pada Lembaga Perkreditan Desa Di Kecamatan Sukawati memiliki rata-rata tinggi. Deviasi Standar 7,186, hal ini berarti bahwa berdasarkan hasil statistik deskriptif terjadi perbedaan nilai efektifitas sistem informasi akuntansi yang diteliti terhadap nilai rata-ratanya sebesar 7,186.

Pada variabel insentif $(Z)$ mempunyai nilai minimum sebesar 6, nilai maksimum sebesar 24, dan nilai rata-rata sebesar 19,21. Hal ini berarti bahwa berdasarkan hasil statistik deskriptif insentif pada Lembaga Perkreditan Desa Di Kecamatan Sukawati memiliki rata-rata tinggi. Deviasi Standar 5,657, hal ini berarti bahwa berdasarkan hasil statistik deskriptif terjadi perbedaan insentif yang diteliti terhadap nilai rata-ratanya sebesar 3,419. Pada variabel kinerja individual (Y) mempunyai nilai minimum sebesar 10 , nilai maksimum sebesar 24 , dan nilai rata-rata sebesar 20,39. Hal ini berarti bahwa berdasarkan hasil statistik deskriptif kinerja individual Pada Lembaga Perkreditan Desa Di Kecamatan Sukawati memiliki rata-rata tinggi. Deviasi Standar 4,733, hal ini berarti bahwa berdasarkan hasil statistik deskriptif terjadi perbedaan kinerja individual yang diteliti terhadap nilai rata-ratanya sebesar 4,733 .

Uji validitas bertujuan untuk mengukur valid atau tidaknya suatu kuesioner, di mana dikatakan valid apabila pernyataan dalam kuesioner mengungkap sesuatu yang akan diukur melalui kuesioner tersebut. Hasil uji validitas dapat dilihat pada Tabel 5 sebagai berikut. Tabel 5 dapat diketahui bahwa seluruh instrumen pernyataan dalam kuesioner yang digunakan untuk 
mengukur variabel efektivitas sistem informasi akuntansi, insentif dan kinerja individual memiliki nilai pearson correlation terhadap skor total lebih besar dari 0,3 sehingga dapat disimpulkan bahwa instrumen yang digunakan dalam penelitian ini telah valid.

Tabel 5.

Hasil Uji Validitas

\begin{tabular}{lccc}
\hline Variabel & Instrumen & R & Keterangan \\
\hline & X1.1 & 0,914 & Valid \\
& X1.2 & 0,935 & Valid \\
& X1.3 & 0,924 & Valid \\
Efektivitas Sistem Informasi Akuntansi $\left(\mathrm{X}_{1}\right)$ & X1.4 & 0,851 & Valid \\
& X1.5 & 0,840 & Valid \\
& X1.6 & 0,878 & Valid \\
& X1.7 & 0,916 & Valid \\
& X1.8 & 0,838 & Valid \\
& Z2.1 & 0,981 & Valid \\
& Z2.2 & 0,951 & Valid \\
Insentif (Z) & Z2.3 & 0,956 & Valid \\
& Z2.4 & 0,926 & Valid \\
& Z2.5 & 0,899 & Valid \\
Z2.6 & 0,939 & Valid \\
Kinerja Individual (Y) & Y1.1 & 0,941 & Valid \\
& Y1.2 & 0,836 & Valid \\
& Y1.3 & 0,961 & Valid \\
& Y1.4 & 0,943 & Valid \\
& Y1.5 & 0,924 & Valid \\
& Y1.6 & 0,903 & Valid \\
\hline
\end{tabular}

Sumber: Data diolah, 2017

Pengujian reliabilitas menunjukkan sejauh mana suatu instrumen yang digunakan beberapa kali untuk mengukur suatu obyek yang sama, akan menghasilkan data yang sama. Suatu instrumen dikatakan reliabel jika nilai croncbach's alpha lebih besar dari 0,6 (Ghozali,2006:33). Tabel 6 berikut akan menyajikan hasil uji reliabilitas instrumen penelitian. 
Tabel 6.

Hasil Uji Reliabilitas

\begin{tabular}{lcc}
\hline \multicolumn{1}{c}{ Variabel } & Cronbach's Alpha & Keterangan \\
\hline Efektivitas Sistem Informasi & 0,962 & Reliabel \\
Akuntansi ( $\left.\mathrm{X}_{1}\right)$ & 0,974 & Reliabel \\
Insentif (Z) & 0,961 & Reliabel \\
KinerjaIndividual (Y) & &
\end{tabular}

Berdasarkan Tabel 6 diketahui bahwa nilai cronbach's alpha masingmasing variabel lebih besar dari 0,60 sehingga dapat disimpulkan bahwa semua pernyataan yang digunakan dalam penelitian ini telah reliabel. Agar model regresi layak untuk dianalisis, maka model regresi tersebut harus memenuhi asumsi klasik, yaitu berdistribusi normal, serta terbebas dari gejala multikolinearitas, autokorelasi, dan heteroskedastisitas. Dalam penelitian ini, akan dilakukan pengujian normalitas dan heteroskedastisitas data untuk melihat apakah model regresi telah memenuhi atau tidak asumsi klasik.

Uji normalitas bertujuan untuk menguji normal atau tidaknya distribusi suatu data, di mana pengujian dilakukan dengan menggunakan uji statistik Kolmogorov Smirnov. Hasil uji normalitas dapat dilihat pada Tabel 7 sebagai berikut.

Tabel 7.

Hasil Uji Normalitas

\begin{tabular}{ll}
\hline & Unstandardized Residual \\
\hline $\mathrm{N}$ & 99 \\
Kolmogorov-Smirnov $Z$ & 1,086 \\
Asymp.Sig.(2-tailed) & 0,120 \\
\hline Simber: Dataid) &
\end{tabular}

Sumber: Data diolah, 2017

Pada tabel 7 menunjukkan bahwa nilai Kolmogorov Smirnov (K-S) sebesar 1,086, sedangkan nilai Asymp. Sig. (2-tailed) sebesar 0,120. Hasil tersebut 
I Kadek Indra Suryawan dan I Gusti Ngurah Agung Suaryana. Pengaruh...

mengindikasikan bahwa model persamaan regresi tersebut berdistribusi normal karena nilai Asymp. Sig. (2-tailed) 0,120 lebih besar dari nilai alpha 0,05.

Uji heteroskedastisitas bertujuan untuk menguji apakah terdapat ketidaksamaan varians dari residual satu pengamatan ke pengamatan lainnya dalam model regresi. Hasil uji heteroskedastisitas dapat dilihat pada Tabel 8 sebagai berikut.

Tabel 8.

Hasil Uji Heterokedastisitas

\begin{tabular}{lll}
\hline Variabel & Sig. & Keterangan \\
\hline Efektivitaas Sistem Informasi Akuntansi (X1) & 0,557 & Bebas Heteroskedastisitas \\
Insentif(Z) & 0,133 & Bebas Heteroskedastisitas \\
X1Z & 0,070 & Bebas Heteroskedastisitas \\
\hline
\end{tabular}

Sumber: Data diolah, 2017

Tabel 8 menunjukkan bahwanilai Sig. dari seluruh variabel lebih besar dari 0,05 yang berarti tidak terdapat pengaruh antara variabel bebas terhadap absolute residual. Dengan demikian, model yang dibuat tidak mengandung gejala heteroskedastisitas. Moderated Regression Analysis (MRA) bertujuan untuk dapat mengetahui apakah insentif dapat memoderasi hubungan antara efektivitas sistem informasi akuntansi terhadap kinerja individual. Berikut hasil analisis regresi moderasi disajikan pada Tabel 9 sebagai berikut.

Tabel 9.

Hasil Uji Analisis Regresi Moderasi

\begin{tabular}{|c|c|c|c|c|c|}
\hline Variabel Terikat & $\begin{array}{c}\text { Variabel } \\
\text { Bebas }\end{array}$ & $\begin{array}{c}\text { Koefisien } \\
\text { Regresi }\end{array}$ & $\begin{array}{c}\text { Standar } \\
\text { Error }\end{array}$ & t- hitung & Sig. \\
\hline \multirow{3}{*}{ Kinerja Individual } & $\mathrm{X}_{1}$ & 0,321 & 0,052 & 6,187 & 0,000 \\
\hline & $\mathrm{Z}$ & 0,160 & 0,071 & 2,247 & 0,027 \\
\hline & $\mathrm{X} 1 \mathrm{Z}$ & 0,006 & 0,002 & 2,769 & 0,007 \\
\hline \multicolumn{2}{|c|}{$=6,140$} & & F-Hitung & $=95,284$ & \\
\hline Adjusted R Square & $=0,751$ & & Sig. & $=0.000$ & \\
\hline
\end{tabular}

Sumber: Data diolah, 2017

$$
\mathrm{Y}=6,140+0,321 \mathrm{X} 1+0,160 \mathrm{Z}+0,006 \mathrm{X} 1 \mathrm{Z}+\mathrm{e}
$$


Nilai konstanta $(\alpha)$ sebesar 6,140 dan bernilai positif memiliki arti bahwa apabila efektivitas sistem informasi akuntansi (X1) bernilai nol, maka kinerja individual (Y) akan bernilai 6,140 satuan. Nilai koefisien $\beta 1=0,321$ memiliki arti bahwa peningkatan efektivitas sistem informasi akuntansi (X1) akan meningkatkan pula kinerja individual (Y) dengan asumsi variabel bebas lainnya tetap. Nilai koefisien $\beta 2=0,160$ memiliki arti bahwa peningkatan insentif $(\mathrm{Z})$ akan meningkatkan pula kinerja individual $(\mathrm{Y})$ dengan asumsi variabel bebas lainnya tetap. Nilai koefisien $\beta 3=0,006$ memiliki arti bahwa efek moderasi yang dihasilkan adalah positif, sehingga semakin tinggi moderasi insentif (Z), maka akan meningkatkan pengaruh efektivitas sistem informasi akuntansi (X1) pada kinerja individual (Y).

Koefisien determinasi dilihat dari besarnya nilai adjusted $\mathrm{R}^{2}$ sebesar 0,751 . Artinya bahwa 75,1 persen variasi kinerja individual mampu dijelaskan oleh variabel efektivitas sistem informasi akuntansi, insentif, dan interaksi antara efektivitas sistem informasi akuntansi dengan insentif. Sisanya sebesar 24,9\% dijelaskan oleh variabel lainnya diluar model penelitian. Dalam penelitian ini, diperoleh juga nilai sig. Fhitung $=0,000$, sehingga sig. Fhitung tersebut lebih kecil dari $\alpha=0,05$. Hal ini memiliki arti bahwa variabel efektivitas sistem informasi akuntansi, insentif, dan interaksi antara efektivitas sistem informasi akuntansi dengan insentif secara simultan mampu menjelaskan secara signifikan variabel kinerja individual.

Pengujian hipotesis dapat dilihat dari signifikansi hasil uji t masing-masing variabel pada Tabel 9. Pada hipotesis pertama $\left(\mathrm{H}_{1}\right)$ dikemukakan bahwa 
I Kadek Indra Suryawan dan I Gusti Ngurah Agung Suaryana. Pengaruh...

efektivitas sistem informasi akuntansi berpengaruh positif pada kinerja individual. Hasil menunjukan bahwa nilai tingkat signifikansi t sebesar $0,000<\alpha=0,05$ sehingga dapat disimpulkan bahwa $\mathrm{H} 1$ diterima. Pada hipotesis kedua $\left(\mathrm{H}_{2}\right)$ dikemukakan bahwa insentif mampu memoderasi pengaruh efektivitas sistem informasi akuntansi terhadap kinerja individual. Hasil menunjukan bahwa nilai tingkat signifikansi t sebesar $0,007<\alpha=0,05$ sehingga dapat disimpulkan bahwa $\mathrm{H}_{2}$ diterima.

Berdasarkan hasil uji parsial pengaruh efektivitas sistem informasi akuntansi pada kinerja individual, diketahui bahwa efektivitas sistem informasi akuntansi berpengaruh positif dan signifikan terhadap kinerja individual. Hal ini memiliki arti bahwa peningkatan pada efektivitas sistem informasi akuntansi akan meningkatkan pula kinerja individual. Hasil ini didukung oleh teori Technology Acceptance Model yang menyatakan bahwa perilaku pengguna sistem informasi didasarkan pada persepsinya mengenai kebermanfaatan dan kemudahan penggunaan sistem tersebut, sehingga jika sistem informasi akutansi tersebut semakin efektif di mana dapat digunakan secara mudah serta memberikan manfaat bagi individu atau karyawan, maka individu atau karyawan tersebut akan menggunakan sistem informasi akuntansi tersebut dengan baik, dan kemudian berdampak pada kinerja individual yang semakin meningkat pula. Sebaliknya, apabila sistem informasi akuntansi tersebut tidak efektif di mana sulit untuk digunakan serta tidak memberikan manfaat bagi individu atau karyawan, maka individu atau karyawan tersebut akan tidak maksimal dalam menggunakan sistem informasi akuntansi tersebut atau bahkan menolak menggunakannya, dan 
kemudian berdampak pada kinerja individual yang akan mengalami penurunan. Hasil ini juga sejalan dengan penelitian Wahyu (2012), Aditya dan Suardika (2013), Marlita dan Darmadiaksa (2014) dan Suratini (2015) yang menyatakan bahwa terdapat hubungan positif dan signifikan antara efektivitas sistem informasi akuntansi dengan kinerja individual.

Berdasarkan hasil uji moderasi pengaruh efektivitas sistem informasi akuntansi dan insentif pada kinerja individual, diketahui bahwa insentif mampu memoderasi pengaruh efektivitas sistem informasi akuntansi terhadap kinerja individual. Hal ini memiliki arti bahwa peningkatan insentif yang diberikan akan meningkatkan pula efektivitas sistem informasi akuntansi sehingga berdampak pada semakin baiknya kinerja individual. Hal ini dikarenakan, semakin efektif sistem informasi akuntansi akan membuat kinerja semakin tinggi. Jadi dengan adanya insentif sebagai motivasi yang mendorong kinerja karyawan menjadi lebih baik lagi, diharapkan dapat meningkatakan pengaruh efektivitas sistem informasi terhadap kinerja individual. Didukung pula dengan pernyataan dari Casio (1995:377) yang menyebutkan insentif adalah variabel penghargaan yang diberikan kepada individu dalam suatu kelompok, yang diketahui berdasarkan perbedaan dalam mencapai hasil kerja. Hasil ini juga sejalan dengan penelitian Dwijayanthi (2013) yang mengatakan bahwa insentif berpengaruh positif dan signifikan terhadap kinerja individu pengguna sistem informasi akuntansi.

\section{SIMPULAN}

Berdasarkan pembahasan hasil penelitian di atas, dapat disimpulkan bahwa efektivitas sistem informasi akuntansi berpengaruh positif terhadap kinerja 
I Kadek Indra Suryawan dan I Gusti Ngurah Agung Suaryana. Pengaruh...

individual pada Lembaga Perkreditan Desa di Kecamatan Sukawati dan insentif mampu memoderasi pengaruh efektivitas sitem informasi akuntansi terhadap kinerja individual pada Lembaga Perkreditan Desa di Kecamatan Sukawati. Sementara itu, saran yang dapat diberikan adalah diharapkan Lembaga Perkreditan Desa di Kecamatan Sukawati agar tetap memperhatikan kualitas sistem informasi akuntansi baik dari segi sistemnya maupun kualitas kemampuan pengguna sistem tersebut. Bagi pengguna sistem ataupun teknologi lainnya, sebaiknya dilakukan pelatihan sebelum bekerja, serta lebih ditingkatkan lagi kesesuaian antara insentif yang diberikan dengan beban kerja yang telah dilakukan karyawan, dengan demikian akan dapat meningkatkan kinerja individu serta organisasi secara keseluruhan. Bagi peneliti selanjutnya disarankan untuk memperluas ruang lingkup wilayah penelitian tidak hanya pada Lembaga Perkreditan Desa melainkan bisa juga di bidang lainnya serta pada perusahaan lainnya yang berbeda agar lebih mampu melakukan generalisasi pada hasil penelitian. Peneliti selanjutnya juga dapat mengganti variabel moderasi yang lain seperti tingkat pendidikan ataupun lainnya dan menambah variabel lainnya yang mungkin berhubungan dengan penelitian mengenai aspek keperilakuan sistem informasi akuntansi.

\section{REFERENSI}

Aditya, P. P. dan I. M. Sadha Suardikha. (2013). Keahlian Pemakai Komputer dan Kenyamanan Fisik Memoderasi Pengaruh Efektivitas Sistem Informasi Akuntansi Terhadap Kinerja Karyawan di PT. Bank Sinar Harapan Bali Denpasar. E-Jurnal Akuntansi Universitas Udayana, 5(2), 361-381.

Damayanthi, I. G. A. E. (2012). Pengaruh Efektivitas Sistem Informasi Akuntansi Dan PenggunaanTeknologi Informasi Terhadap Kinerja Individual 
PadaKoperasi Simpan Pinjam Di Kecamatan Denpasar Barat. Jurnal Riset Akuntansi Juara, 2(1), 40-52.

Davis, F. D. (1989). Perceived Usefulness, Perceived Ease of Use, and Acceptance of Information System Technology. Management Information Systems Quarterly, 13(3), 319-339.

Deny, L. G. dan I. K. Suryanawa. (2014). Penerapan Sistem Informasi Akuntansi Pada Bank Perkreditan Rakyat Sari Jaya Sedana Klungkung.

Dwijayanthi, D. M. (2013). Pengaruh Insentif Tingkat Pendidikan, Pelatihan Dan Pengalaman Kerja Pada Kinerja Individual Pengguna Sistem Informasi.

Efferin, S., S. H. Darmadji dan U. Tan. (2008) Metode Penelitian Akuntansi. Yogyakarta: GrahaIlmu

George, N. O., E. M. Stephen., M. R. Nyamao., and P. Kibet. (2012). Factors Influencing Employee Performance Appraisal System. International Journal of Business and Social Science, 3(20), 37-46.

Ghozali, Imam. (2011). Aplikasi Analisis Multivariate dengan Program IMB SPSS19. Edisi Kelima. Semarang: Badan Penerbit Universitas Diponegoro.

Gupta, M. P., S. Kanungo., R. Kumar., and G. P. Sahu. (2007). "A Study of Information Technology Efectiveness in Select Government Organization in India". Journal for Decision Makers, 32(2).

Handoko, T. H. (2002). Manajemen Personalia dan Sumber Daya Manusia. Edisi II. Catatan Keempat Belas. Yogyakarta Penerbit BPFE.

Indra, L. W., \& I. G. Agung Suaryana. (2014). Pengaruh Penerapan Sistem Informasi Akuntansi Terhadap Kinerja Individu pada Usaha Kecil dan Menengah di Nusa Penida. E-Jurnal Akuntansi Universitas Udayana, 7(3), 529-546.

Kelton, A. S., R. R. Pennington dan B. M. Tuttle. (2010). "The effects of Information Presentation Format on Judgement and decision Making: A Review of The Information System Research". Journal of Information System, 24(2), 79-105.

Kharuddin, S., M. A. Nassir., and M. Z. Ashhari. (2010). Information System and Firms' Performance: The Case of Malaysian Small Medium Enterprises. International business research, 3(4), 33. 
Kouser, R., A. Shahzad and A. Rana. (2011). Firm Size, Leveragee and Profitability: Overriding Impact of Accounting Information System. Journal of Management and Business Review, 1(10), 58-64.

Liana, L. (2009). Penggunaan MRA dengan SPSS untuk Menguji Pengaruh Variabel Moderating terhadap Hubungan Antara Variabel Independen dan Variabel Dependen. Jurnal Teknologi Informasi DINAMIK, 14(2), 90-97.

Lindawati, H., dan I. Salamah. (2012). Pemanfaatan Sistem Informasi dan Teknologi Informasi Pengaruhnya Terhadap Kinerja Individual Karyawan. Jurnal Akuntansi dan Keuangan, 14(1), 56-68.

Marlinawati, N. M. A. dan Suaryana, G. N. A. (2012). Pengaruh Penggunaan Teknologi Informasi, Efektivitas Sistem Informasi Akuntansi, Kepercayaan Atas Sistem Informasi Akuntansi, dan Kesesuaian Tugas pada Kinerja Karyawan Lembaga Perkreditan Desa di Kabupaten Badung. E-Jurnal Akuntansi Universitas Udayana, 388-401.

Marlita, N. M. P. A., dan I. B. Dharmadiaksa. (2014). Pengaruh Efektivitas Penerapan Sistem Informasi Akuntansi, Pemanfaatan dan Kesesuaian Tugas pada Kinerja Karyawan. E-Jurnal Akuntansi Universitas Udayana, 9(2), 373-384.

Mercika., N. D. T. Jati, dan I. K. Jati. (2015). Kemudahan Penggunaan Sistem Sebagai Moderasi Pengaruh Efektivitas Sistem Informasi Akuntansi pada Kinerja. E-Jurnal Akuntansi Universitas Udayana, 10(3), 723-737.

Novita, H. (2011). Efektivitas Sistem Informasi Akuntansi Dampaknya Terhadap Kinerja Karyawan pada PT. Dwi Daya Sentra Perkasa (persero). Skripsi. Fakultas Teknik dan Ilmu Komputer Universitas Komputer Indonesia.

Nwokeji, E. N. A. (2012). Repositioning Accounting Information System Through Effective Data Quality Management: A Framework For Reducing Costs And Improving Performance. International Journal Of Scientific \& Technology Research, 1(10).

Puja, A dan I. M. S. Suardikha. (2013). Keahlian Pemakai Komputer dan Kenyamanan Fisik Memoderasi Pengaruh Efektivitas Sistem Informasi Akuntansi pada Kinerja Karyawan di PT. Bank Sinar Harapan Bali Denpasar. E-Jurnal Akuntansi Universitas Udayana, 5(2), 361-381.

Puji, A., dan I. B. Dharmadiaksa. (2014). Pengaruh Efektivitas Penerapan Sistem Informasi Akuntansi, Pemanfaatan dan Kesesuain Tugas Terhadap Kinerja Karyawan, E-Jurnal Akuntansi Universitas Udayana, 9(2), 373-384. 
Salehi, M., Rostami, Vahab, dan M. Abdolkarim. (2010). Usefulness of Accounting System in Emerging Economy; Evidence of Iran. International Journal of Economics and Finance, 2(2), 186-195.

Soudani, S. N. (2012). The Usefulness of an Accounting Information System for Effective Organisational Performance. International Journal of Economics and Finance, 4(5), 136-145.

Sugiyono. (2013). Metode Penelitian Bisnis. Bandung: Alfabeta.

Suratini, N. P. E. (2015). Pengaruh Efektivitas Sistem Informasi Akuntansi dan Penggunaan Teknologi Informasi Akuntansi Terhadap Kinerja Individual pada PT. Bank Pembangunan Daerah Bali Kantor Cabang Singaraja. EJurnal Akuntansi Universitas Pendidikan Ganesha, 3(1), 1-19.

Suryandari, N. (2011). Diklat Analisis Kinerja Perusahaan. Purworejo: STIE Rajawali.

Sugiartini, N. M. (2016). Pengaruh Teknologi Sistem Informasi Akuntansi pada Kinerja Individu dengan Budaya Organisasi sebagai Pemoderasi. E-Jurnal Universitas Udayana, 14(3), 1867-1894.

Urquia, E. (2011). The Impact of Accointing Information System (AIS) on Performance measures: Empirical evidence in Spanish SMEs1. Journal International of Digital Accounting Research. 11(2), 25-43.

Wahyu, K. (2012). Analisis Pengaruh Efektivitas Sistem Informasi Akuntansi Terhadap Kinerja Individual Pegawai PT. KIM ENG Sekuritas Indonesia. Skripsi pada Fakultas Ekonomi Universitas Gunadarma.

Yamit, Z. (2003). Manajemen Produksi dan Operasi, Edisi 2. Ekonisia. Yogyakarta 